ARCHIWA，BIBLIOTEKI

I MUZEA KOŚCIELNE 112 (2019)

https://doi.org.10.31743/abmk.2019.112.22

\title{
DYDAKTYKA UNIWERSYTECKA W PRZESTRZENI MUZEUM RELIGIJNEGO. ZAJECIA PRAKTYCZNE DOKUMENTACJA OBIEKTÓW I RZEMIOSEO ARTYSTYCZNE DLA STUDENTÓW MUZEOLOGII UKSW W MUZEUM ARCHIDIECEZJI WARSZAWSKIEJ
}

\begin{abstract}
Streszczenie
Niniejszy tekst prezentuje zajęcia praktyczne z przedmiotów Rzemiosło artystyczne oraz Dokumentacja obiektów dla studentów UKSW, które odbywały się w Muzeum Archidiecezji Warszawskiej. Wyszczególnione zostały szczególnie aspekty kursu, który odbywał się w muzeum, jako, że treści teoretyczne wykładane były w warunkach akademickich. Niezwykle ważne okazało się skonfrontowanie wiedzy nabytej podczas wykładów i ćwiczeń z praktycznym kursem dokumentacji obiektów, który w założeniu stanowi integralną część studiów licencjackich na kierunku Muzeologia. Z uwagi na brak muzeum uniwersyteckiego, było kwestią kluczową by zapewnić studentom środowisko, w którym wiedza teoretyczna zostałaby skonfrontowana $\mathrm{z}$ praktyką muzealniczą. Tekst analizuje najważniejsze aspekty zajęć w Muzeum Archidiecezji Warszawskiej, które pozwoliły studentom na pracę w profesjonalnym środowisku muzealnym.
\end{abstract}

Słowa kluczowe: muzealnictwo, rzemiosło artystyczne, sztuka dekoracyjna, dokumentacja obiektów, sztuka religijna, muzeum wyznaniowe, dydaktyka

Muzeologia, kierunek otwarty na Uniwersytecie Kardynała Stefana Wyszyńskiego w Warszawie w 2016 r., to studia humanistyczne, których zadaniem jest przygotowanie przyszłych absolwentów do pracy w instytucjach kultury, głównie o profilu wystawienniczym ${ }^{1}$.

* Anna Wiśnicka - dr historii sztuki; adiunkt w Instytucie Kulturoznawstwa Uniwersytetu Kardynała Stefana Wyszyńskiego w Warszawie; e-mail: a.wisnicka@uksw.edu.pl

https://orcid.org/0000-0002-6821-529X

${ }^{1}$ Studia pierwszego stopnia (licencjackie) otwarto w październiku 2016 r. na Wydziale Nauk Humanistycznych UKSW w Warszawie. Działająca tam Katedra Muzeologii prowadziła również specjalizację muzeologiczną dla studentów wydziału. 
Jak przeczytać można w oficjalnych informacjach na stronie kierunku

- ukończone studia stwarzają ich absolwentom szansę na znalezienie pracy w licznych istniejących i powstających na terenie Polski muzeach, ale także w innych instytucjach kultury: galeriach wystawienniczych, w czasopismach i wydawnictwach o profilu humanistycznym, w prywatnych firmach zajmujących się obrotem dziełami sztuki, czy wreszcie w szkolnictwie podstawowym i ponadpodstawowym ${ }^{2}$.

Studia, by spełnić swe podstawowe zadanie jakim jest wdrożenie przyszłych muzeologów do pracy w placówkach o tymże profilu, muszą połączyć szereg przedmiotów o charakterze teoretycznym z licznymi zajęciami terenowymi, które odbywają się z założenia w muzeach i galeriach sztuki. Dzięki połączeniu teorii z praktyką in situ $\mathrm{w}$ instytucjach muzealnych, przyszli adepci dogłębnie poznają meandry pracy oraz wymogi, którym będą musieli w przyszłości sprostać zarówno na polu intelektualno-naukowym jak i organizacyjnym. Niezwykle przydatne w osiągnięciu założonych celów dydaktycznych wydają się zbilansowane proporcje między przedmiotami humanistycznymi takimi jak historia sztuki, historia kultury, historia designu, rzemiosło artystyczne, kultura antyczna, archeologia, socjologia, filozofia, etnografia czy historia literatury, z przedmiotami o charakterze ściśle muzeologicznym, wśród których wspomnieć należy choćby historię kolekcjonerstwa, architekturę muzeum, publikacje muzealne, dokumentację obiektów, wstęp do muzeologii, wystawiennictwo oraz prawo w muzeum ${ }^{3}$.

Przyglądając się pozycji studiów muzeologicznych na mapie polskiego szkolnictwa wyższego daje się zauważyć, iż jest to kierunek niszowy, skierowany głównie do osób pragnących uzupełnić swoje wykształcenie. Jak podaje baza informacji Narodowego Instytutu Muzealnictwa i Ochrony Zbiorów, wśród ponad czterdziestu ofert edukacyjnych w sektorze szkolnictwa wyższego, jedynie dwie placówki oferują stacjonarne studia na kierunku muzeologia - Uniwersytet Kardynała Stefana Wyszyńskiego w Warszawie i Uniwersytet Rzeszowski. Pozostała część to studia niestacjonarne lub podyplomowe, część o profilu stricte muzeologicznym, przeważająca jednak większość oferuje kształcenie o profilu kulturoznawczym z elementami wiedzy o muzeach ${ }^{4}$. $Z$ danych tych jasno wynika, iż jest to na polskich uniwersytetach kierunek specjalistyczny, a także relatywnie młody, biorąc pod uwagę, że pierwsze studia muzealnicze prowadzone przez Uniwersytet Mikołaja Kopernika w Toruniu otworzyły swe podwoje dla studentów dopiero pod koniec lat 70. XX wieku, a od 1991 r. studia te zastąpił nowy kierunek - ochrona dóbr kultury. Nie dziwi więc znikoma ilość literatury poświęconej historii uprawiania muzeologii oraz jej metodyki na poziomie akademickim.

Stan badań dotyczący historii uniwersyteckiej humanistyki w Polsce jest wciąż polem, które czeka na staranne opracowanie. Istnieją fragmentaryczne próby ujęcia tematu, czego przykładem są prace dotyczące rozwoju historii sztuki

${ }^{2}$ Zob. Perspektywy zawodowe absolwenta na www.uksw.edu.pl/node/920 (dostęp: 01.07.2018).

${ }^{3}$ Kompletny wykaz przedmiotów zawartych w programie studiów I stopnia, zob. Aneks 1.

${ }^{4}$ Por. Baza studiów skierowanych do muzealników i osób związanych z muzealnictwem, NIMOZ nimoz.pl/baza-wiedzy/bazy-danych/baza-studiow-dla-muzealnikow/studia-w-polsce?pdf $=1$ (dostęp: 29.12.2019). 
w na ziemiach polskich i utworzenie polskiej szkoły historii sztuki, by wspomnieć tylko prace Adama Bochnaka ${ }^{5}$, Piotra Skubiszewskiego ${ }^{6}$ czy Jana Białostockiego ${ }^{7}$ prezentujące i analizujące rozwój i metodologię dyscypliny w szerokim kontekście kulturowym, z uwzględnieniem najważniejszych ośrodków dydaktyczno-badawczych. Niestety w polskim dyskursie nie funkcjonują publikacje, które uwzględniałyby ten rodzaj badań na gruncie muzeologicznym. Dydaktyka przedmiotów humanistycznych na wyższych uczelniach, rozwijająca się w krajach europejskich nie stanowiła do tej pory tematów rozważań polskich naukowców W obrębie tematyki, której poświęcono niniejszy tekst ${ }^{8}$. W globalnych badaniach nad kwestiami związanymi z szeroko pojętymi badaniami muzeologicznymi ważnym ujęciem jest praca A Bibliography of Museum Studies ${ }^{9}$, która zebrała anglojęzyczne piśmiennictwo naukowe w tej dziedzinie. Choć praca jest bardzo obszerna i porusza istotne kwestie takie jak kolekcje w Europie, Azji i Stanach Zjednoczonych, edukację muzealną, architekturę muzeum czy zarządzanie muzeami, to nie podnosi problemu dotyczącego kształcenia przyszłych muzeologów ani metod dydaktycznych, które winny być zastosowane w celu uzyskania optymalnego poziomu edukacji przygotowującego do pracy w muzach. Do ważnych pozycji, które oscylują wokół problematyki muzeologicznej zaliczyć należy przede wszystkim wydawnictwo Międzynarodowej Rady Muzeów ICOM - A History of Museology. Key authors of museological theory ${ }^{10}$, przybliżającą zagadnienia rozwoju dyscypliny oraz kluczowe dla niej postaci. Zważywszy na datę publikacji (2019), dają się dostrzec tendencje do eksploracji tego pola, których zapowiedzią były wydane już w XXI wieku kompilacje dotyczące szeroko pojętych praktyk związanych $\mathrm{z}$ uprawianiem muzeologii, jak prace pod redakcją Bettiny M. Carbonell ${ }^{11}$ i Sharon Macdonald ${ }^{12}$.

Jedną z nielicznych pozycji, która na gruncie międzynarodowym w szeroki stopniu bada źródła oscylujące wokół zagadnień muzeologicznych, jest praca Keyguide to Information Sources in Museum Studies ${ }^{13}$. Pewne sygnały dotyczące edukacji studentów uczelni wyższych w przestrzeniach muzealnych, jedynie jednak w realiach amerykańskich, sygnalizuje praca pod redakcją Barbary Y. New-

${ }^{5}$ A. Bochnak, Zarys dziejów polskiej historii sztuki, Kraków 1948.

${ }^{6}$ P. Skubiszewski, Wstęp do historii sztuki, Warszawa 1973; O dwóch sposobach uprawiania historii sztuki, „Teksty”, 17 (1974) z. 5, s. 56-85; tenże, Moja historia sztuki, „Modus prace z historii sztuki”, 14 (2014) s. 5-22.

${ }^{7}$ J. Białostocki, Historia sztuki wśród nauk humanistycznych, Wrocław 1980.

${ }^{8}$ Najbliższym przykładem komparatystyki dydaktyki humanistycznej, jednakże nie na poziomie uniwersyteckim, jest tekst M. Dolšiny, The Slovenian Art History Textbookin Comparison to Polish Textbooks: Authorship and Content, Didactic Structure and Publishing Circumstances, „Journal of Education Culture and Society”, 1 (2014) s. 285-298.

${ }^{9}$ Praca wydana została po raz pierwszy w 1994 roku, z uzupełnioną reedycją w roku 2016. Zob.

S. J. Knell, A Bibliography of Museum Studies, Nowy York 2016.

${ }^{10}$ B. Brulon Soares, A History of Museology Key authors of museological theory, Paryż 2019.

${ }^{11}$ M. B. Carbonell, Museum Studies: An Anthology of Contexts, Oxford 2012.

${ }^{12}$ S. Macdonald, A Companion to Museum Studies, Oxford 2011.

${ }^{13}$ P. Woodhead, G. Stansfield, Keyguide to Information Sources in Museum Studies, Londyn 1994. 
som i Adele Z. Silver ${ }^{14}$. Rodzime piśmiennictwo poświęca mało miejsca kwestiom zarówno historii muzealnictwa jak i roli dydaktyki w przestrzeniach muzealnych. Rola edukacji muzealnej i cechy, które są domeną kompetentnego muzealnika wybrzmiewają w pozycji Muzea, muzealia, muzealnicy. Ważne rozmowy ${ }^{15}$, która powinna być traktowana jako sugestia dalszych działań badawczych, które mogą przyczynić się do ciągłego podnoszenia jakości kształcenia przyszłych kadr muzealnych. W kontekście stanu piśmiennictwa na temat akademickiego rozwoju przyszłych muzeologów, wydaje się zasadne przybliżenie pewnych zagadnień z tym związanych z perspektywy dydaktyki. Zdzisław Żygulski Jr pisząc o znaczeniu muzeów, ich roli i misji szczególnie podkreślał dydaktyczną rolę zasobów poszczególnych placówek ${ }^{16}$. Podniesienie kwestii współczesnej uniwersyteckiej edukacji muzealników w dyskursie naukowym stanowi więc pole badań, które należy stopniowo eksplorować.

Ważnym etapem w rozwoju zawodowym przyszłych muzeologów jest praca z eksponatami. Ponieważ Uniwersytet Kardynała Stefana Wyszyńskiego w Warszawie nie dysponuje obecnie własnym muzeum ${ }^{17}$, podejmowane są wysiłki, by praktyczną część przedmiotów odbywać w placówkach warszawskich. Obszar zajęć, które wymagają bezpośredniego kontaktu z dziełami sztuki ma kluczowe znaczenie, szczególnie dla studentów drugiego roku studiów, którzy po zakończeniu semestru odbywać będą obowiązkowe praktyki muzealnicze. Ich praktyczne przygotowanie oraz umiejętność właściwej inwentaryzacji artefaktów jest fundamentem, który muszą przyswoić przed samodzielnym wejściem w środowisko muzealne.

Podjęta została decyzja, by o zgodę na przeprowadzenie zajęć zwrócić się do Muzeum Archidiecezji Warszawskiej. Wybór placówki podyktowany był wieloma względami, które warto tu przytoczyć w kontekście merytorycznego przygotowania studentów. Jest to jedyne muzeum kościelne w Warszawie, posiadające niezwykle różnorodne zbiory. Ich specyfika różni się znacznie od zbiorów klasycznego ${ }^{18}$ muzeum czy galerii sztuki nowoczesnej, co samo w sobie ma ogromną wartość poznawczą. Paramenty liturgiczne oraz obrazy i rzeźby o tematyce religijnej stanowiły odrębną grupę artefaktów, wartą przybliżenia, szczególnie w kontekście rzemiosła artystycznego. Nie bez znaczenia była również wielkość placówki. Kameralne muzeum, które nie zatrudnia wielu pracowników jest doskonałym przykładem dobrych praktyk muzealniczych, które prowadzone są przy

${ }^{14}$ B. Y. Newsom, A. Z. Silver, The Art Museum as Educator: A Collection of Studies as Guides to Practice and Policy, Los Angeles 1978, s. 509-567.

${ }^{15}$ P. Jaskanis, Muzea, muzealia, muzealnicy. Ważne rozmowy, Kraków 2016.

${ }^{16}$ Zob. Z. Żygulski Jr, Muzea na świecie. Wstęp do muzealnictwa, Warszawa 1982.

${ }^{17}$ Część uniwersytetów posiada własne kolekcje muzealne, które umożliwiają prowadzenie zajęć lokalnie, w obrębie własnej placówki. Wspomnieć można choćby Muzeum Uniwersytetu Jagiellońskiego, Muzeum Katolickiego Uniwersytetu Lubelskiego Jana Pawła II czy Muzeum Uniwersytetu Warszawskiego. Por. E. Wyka, M. Taborska, University Museums in Poland, „Opuscula Musealia Czasopismo Muzeologiczne", 17 (2009) s. 31-40.

${ }^{18}$ Przez słowo „klasyczne” rozumiem spadek po XIX-wiecznych muzeach, które stanowily zalążki kolekcji narodowych, skupionych więc głównie wokół malarstwa i rzeźby. 
niskich nakładach finansowych. Zajęcia w tego typu placówce pozwalają na poznanie realiów pracy muzealnika, która w przeważającym stopniu skupiona jest w małych, lokalnych muzeach. Duże placówki muzealnicze nie stanowią bowiem w Polsce większości ${ }^{19}$. Warto również dodać, iż muzealnictwo kościelne jest gałęzią ciągle rozwijającą się zarówno w Polsce jak i Europie, a odbyte zajęcia przybliżyły studentom ich rolę zarówno wystawienniczą jak i dydaktyczną ${ }^{20}$.

Muzeum Archidiecezji Warszawskiej, dzięki uprzejmości dyrekcji i pracowników merytorycznych, stało się miejscem, gdzie studenci podjęli pierwsze samodzielne próby dokumentacji obiektów z dziedziny sztuki dekoracyjnej. W zajęciach brali udział studenci Muzeologii oraz specjalizacji Kolekcjonerstwo-Rzeczoznawstwo-Rynek Sztuki. Specjalizacja realizowana jest przez Katedrę Muzeologii UKSW i jest dostępna dla wszystkich studentów Wydziału Nauk Humanistycznych, obejmując następujące kierunki: Kulturoznawstwo, Filologia Klasyczna, Filologia Polska i Filologia Włoska. W ramach specjalizacji studenci kierunków humanistycznych są przygotowywani do pracy w instytucjach wystawienniczych, co pozwala im poszerzyć wachlarz umiejętności pożądanych na rynku pracy ${ }^{21}$. Dzięki programowi składającemu się z przedmiotów łączących podstawy teoretyczne z zajęciami praktycznymi, studenci kierunków innych niż muzeologia również otrzymują odpowiednie przygotowanie do podjęcia pracy w muzeach i galeriach ${ }^{22}$.

Zajęcia w Muzeum Archidiecezji Warszawskiej zostały podzielne na trzy grupy, które ściśle powiązane były z programem studiów na kierunku Muzeologia, jak również z przedmiotami wchodzącymi z zakres specjalizacji Kolekcjonerstwo-Rzeczoznawstwo-Rynek Sztuki. Pierwszy blok obejmował wykład prowadzony przez kustosz Muzeum Archidiecezji Warszawskiej dr Ewę Korpysz oraz dr Beatę Skrzydlewską z Katedry Muzeologii UKSW, który miał za zadnie przybliżyć studentom historię powstania muzeum, funkcje muzeów kościelnych ${ }^{23}$, meandry pracy oraz kontekst występowania kolekcji. Historia i losy placówki były ściśle powiązane z zajęciami z historii muzealnictwa oraz architektury muzeum. Pozwoliło to na utrwalenie oraz rozszerzenie wiadomości obejmujących polskie muzea wyznaniowe w szerszym kontekście muzealnictwa ${ }^{24}$. Poruszono aspekty związane ze specyfiką pracy muzealników w placówce o tak ukierunkowanym profilu dotyczące wystawiennictwa, opracowywania zbiorów oraz orga-

${ }^{19}$ Por. Muzea $w$ Polsce. Raporty na podstawie danych z projektu Statystyka muzeów (20132015), Narodowy Instytut Muzealnictwa i Ochrony Zbiorów, Warszawa 2016.

${ }^{20} \mathrm{~A}$. Rusak, Aktualność pastoralnej $i$ dydaktycznej roli polskich muzeów i skarbców kościelnych, w: Muzea kościelne w perspektywie zadań i trendów wspótczesnego muzealnictwa. Materiaty sesji naukowej w dniach 14-15.06.2012, Katowice 2013, s. 31-38.

${ }^{21}$ Specjalizacja jest dostępna dla studentów WNH UKSW od października 2017 r.

${ }^{22}$ Zob. Aneks 1.

${ }^{23}$ Zob. Funkcja pastoralna muzeów kościelnych, tłum. ks. Fr. Nieckarz, „Biuletyn Muzeum Diecezjalnego", 4 (2000-2001) s. 5-76.

${ }^{24}$ Zob. B. Skrzydlewska, Muzea kościelne w Polsce. Informator, Kielce 2004. 
nizacji wystawy stałej i wystaw czasowych. Podniesione zostały również kwestie prawnego funkcjonowania muzeów religijnych w Polsce ${ }^{25}$.

Pozwoliło to studentom na zapoznanie się $\mathrm{z}$ teorią prezentowaną na zajęciach ze wstępu do muzealnictwa $\mathrm{w}$ wymiarze praktycznym. Najszerzej poruszoną kwestię stanowiła specyfika zbiorów, którymi dysponuje muzeum oraz sposoby ich pozyskiwania. Wymienione zostały grupy obiektów, wokół których zbudowana została wystawa stała oraz artefakty, które znajdują się w magazynach placówki. Dopełnieniem pierwszego bloku zajęć było oprowadzenie kuratorskie po wystawie stałej. Studenci mieli okazję by zobaczyć najważniejsze dzieła z ekspozycji oraz kontekst ich prezentacji oraz by wyróżnić grupy przedmiotów będących w posiadaniu muzeów. Ponadto zwrócono uwagę na projekt wystawy stałej, jej architekturę i wzornictwo oraz wpływ tych czynników na sposoby ekspozycji obiektów.

Tematyką drugiego bloku była inwentaryzacja i sposoby dokumentacji obiektów w muzeum. Zastępca dyrektora Muzeum Archidiecezji Warszawskiej Piotr Plewa oraz dr Ewa Korpysz udostępnili studentom karty inwentaryzacji obiektów ruchomych, które pierwotnie stanowiły podstawy dokumentacji, oraz księgi wpływów muzealiów. Zajęcia dokumentacja obiektów, które przygotowywały studentów do sporząazzenia kart wraz ze szczegółowym opisem, stanowiły teoretyczną bazę. Dzięki zajęciom kursowym uczestnicy mogli porównać profesjonalnie przygotowane dokumenty i zapoznać się z prawidłami ich wypełniania. Podczas zajęć teoretycznych studenci uczyli się podstaw sporządzania dokumentacji zawartych w Ustawie o ochronie zabytków i opiece nad zabytkami ${ }^{26}$ oraz zapoznawali się z prawnymi regulacjami kościelnymi, które dotyczą zabytków ${ }^{27}$. Korzystając z kart inwentaryzacyjnych, ksiąg inwentarzowych oraz ksiąg wpływu, studenci przygotowywali komplet dokumentów, które zwyczajowo stanowiły podstawę klasycznej dokumentacji artefaktów muzealnych. Podczas zajęć obiekty podzielono na grupy - malarstwo, rzeźba oraz rzemiosło artystyczne, co pozwoliło uchwycić meandry technik i materiałów stosowanych do ich wykonania oraz dokładnie przeanalizować najważniejsze aspekty opisu inwentaryzacyjnego. Sam opis stanowił wyzwanie, szczególnie dla studentów specjalizacji, którzy $\mathrm{z}$ tego rodzaju specyfiką tekstu spotkali się po raz pierwszy. Korzystając ze zdjęć wysokiej rozdzielczości, które udostępniane są przez domy aukcyjne ${ }^{28}$ studenci dokładnie oglądali dzieła, analizowali techniki i materiały, treść oraz stan zachowania obiektów. Następnie przygotowywali karty zgodnie z zasadami sztuki.

Drugi blok zajęć w Muzeum Diecezjalnym pozwolił studentom na analizę profesjonalnej dokumentacji. Analizowali oni karty inwentaryzacyjne przygotowane przez pracowników muzeum oraz księgi inwentarzowe. Dr Ewa Korpysz

${ }^{25}$ M. Leszczyński, Muzea kościelne wg aktualnego prawodawstwa kościoła katolickiego, „Archiwa, Biblioteki i Muzea Kościelne”, 85 (2006) s. 103-118.

${ }^{26}$ Ustawa z dnia 23 lipca 2003 r. o ochronie zabytków i opiece nad zabytkami.

${ }^{27}$ B. Skrzydlewska, Uregulowania prawne kościoła rzymskokatolickiego dotyczace ochrony zabytków, ABMK 77 (2002) s. 287-316.

${ }^{28} \mathrm{~W}$ przypadku malarstwa zdjęcia obiektów pochodziły ze zbiorów brytyjskiego domu aukcyjnego Sotheby's, rzemiosło artystyczne z kolekcji szwedzkiego Modernity. 
wyłożyła studentom najważniejsze kwestie związane z fizyczną dokumentacją obiektów oraz hierarchię najważniejszych faktów, które muszą znaleźć się $\mathrm{w}$ dokumentach. Zabieg ten był bardzo pomocny, utwierdził bowiem studentów w przekonaniu, że do każdego obiektu należy podejść indywidualnie, stosując jednakże zalecenia ustawodawcy.

Zajęcia w Muzeum Archidiecezjalnym zamknęła kwestia poruszona przez Piotra Plewę - cyfrowa dokumentacja obiektów. Obecnie większość placówek wystawienniczych pracuje w wirtualnych bazach danych. Pozwala to na szybkie znalezienie dzieł sztuki, sortowanie obiektów według daty, techniki wykonania, materiału itp. Dzięki wdrożeniu cyfrowej archiwizacji w łatwy sposób można dokonać selekcji dzieł pod kątem wystaw czasowych czy decyzji dotyczących wypożyczeń obiektów. Ponadto bazy danych pozwalają na udostępnianie zbiorów w trybie zamkniętym między placówkami muzealnymi oraz selekcję dzieł, które stanowić będą trzon ogólnodostępnego zdigitalizowanego archiwum danego muzeum. Systemy cyfrowe skutecznie zastępują obecnie klasyczny system dokumentacji obiektów lub w niektórych przypadkach są równoważną metodą.

Studenci zapoznali się ze sposobami działania cyfrowej bazy danych ${ }^{29} . \mathrm{Na}$ wstępie pracownicy muzeum zaprezentowali system MONA, w którym pracuje wiele placówek muzealnych w Polsce i za granicą ${ }^{30}$. Wytłumaczyli studentom wady i zalety systemu w odniesieniu do placówki, jaką jest muzeum wyznaniowe, które ma określony schemat finansowania i limity, które muszą być wzięte pod uwagę we wszystkich aspektach pracy. Dzięki takiemu podejściu przyszli muzeolodzy mieli okazję by zrozumieć, jakie mechanizmy kierują pracą w rozmaitych typach muzeów. Piotr Plewa zaprezentował system katalogowania zbiorów, na którym Muzeum Archidiecezji Warszawskiej oparło prace dokumentacyjne - ArtSaas. Odejście od popularnej MONY podyktowane zostało zarówno względami ekonomicznymi jak i praktycznymi, pozwoliło bowiem na bezpośrednie dodawanie do bazy zdjęć w wysokiej rozdzielczości, które stanowiły podstawę prac digitalizacyjnych. Studenci poznali sposób funkcjonowania bazy danych oraz jej możliwości wykorzystywane w codziennych praktykach muzealnych. Dowiedzieli się, jakie informacje wprowadzane są do systemu i na jakie elementy trzeba zwrócić szczególną uwagę. Pozwoliło to też na komparatystykę klasycznych metod sporządzania dokumentacji z nowoczesnymi. Karty, choć zawierają w podstawowej wersji więcej rubryk, ograniczają ilościowo opisy. Wirtualny system umożliwia personalizację rubryk w zależności od charakteru dzieła sztuki, nie ma ograniczeń pod względem ilości wprowadzanego tekstu, a zdjęcia obiektów wysokiej jakości stanowią jego integralną część. Dzięki szczegółowemu przedstawieniu systemu ArtSaas studenci doświadczyli, jak bardzo złożonym tematem

${ }^{29}$ Por. Program digitalizacji dóbr kultury oraz gromadzenia, przechowywania i udostępniania obiektów cyfrowych w Polsce 2009-2020, Warszawa 2009.

${ }^{30}$ Studenci muzeologii zostali zapoznani z prawidłami działania systemu MONA podczas wizyty w Ośrodku Sztuki Muzeum Zamku Królewskiego w Warszawie. Dzięki uprzejmości dr Anny Szkurłat, która oprowadziła studentów po kolekcji porcelany i fajansu oraz pokazała zasady działania e-katalogowania, przyszli adepci muzeologii dowiedzieli się jak w praktyce działa system MONA. 
jest dokumentacja, która stanowi podstawę wielu działań muzealników. Wizyty w muzeum stopniowo uświadamiały żakom jak ważną rolę pełni dokumentacja obiektów. Od profesjonalnego i rzetelnego opracowania zależy bowiem sprawne funkcjonowanie muzeum. Czas poświęcony na przygotowanie bardzo szczegółowej karty inwentaryzacyjnej, kwerenda pozwalająca na rozpoznanie proweniencji obiektu i jego datowanie oraz ciągłe dokształcanie się muzealnika w dziedzinie sztuki i rzemiosła artystycznego stanowią nieodłączny element codzienności muzealnej.

Ostatni blok zajęć w muzeum obejmujący pracę z przygotowanymi przez kustosz obiektami odbył się pod koniec semestru letniego. Był to celowy zabieg, dzięki któremu studenci mieli za sobą większą część teoretyczną zajęć oraz kilka prób samodzielnego przygotowania kart inwentarzowych w warunkach uniwersyteckich, przy braku fizycznie dostępnych obiektów. Zajęcia w Muzeum Archidiecezji Warszawskiej miały skonfrontować adeptów dokumentacji z obiektami z kolekcji placówki, których karty stanowiły podstawę zaliczenia przedmiotu. Do opisu wybrane zostały cztery artefakty, obejmujące działy sztuki i rzemiosła artystycznego, z którymi najczęściej spotykają się muzealnicy. Pierwszy z nich to XIX-wieczny obraz nieznanego autora z przedstawieniem Jana Chrzciciela $\mathrm{z}$ małym Jezusem. Dzieło wykonano w technice olejnej na tekturze, zachowane w dobrym stanie; jedynymi uwagami konserwatorskimi były drobne spękania w warstwie werniksu. Łatwy do identyfikacji motyw ikonograficzny oraz stosunkowo niewielka liczba szczegółów na obrazie pozwoliły studentom na dużą samodzielność w pracy nad dokumentacją, pomimo ograniczonego do 60 godzin kursu historii sztuki.

Drugim dziełem, z którym przyszło się zmierzyć studentom była XIX-wieczna rzeźba trójpostaciowa o nieznanej proweniencji, przedstawiająca koronację Maryi przez Boga Ojca i Jezusa. Polichromowana, drewniana rzeźba miała nieopracowany tył oraz liczne ubytki i przetarcia. Opis tego rodzaju obiektu stanowił wyzwanie, szczególnie biorąc pod uwagę z jaką starannością i szczegółowością zwykło się przedstawiać stan zachowania obiektu i potrzeby konserwatorskie. Rzeźba z ubytkami była przeciwieństwem prac, z którymi mieli do czynienia studenci podczas zajęć teoretycznych.

Trzeci i czwarty obiekt należały do grupy zabytków określanych jako rzemiosło artystyczne. Reprezentantem złotnictwa był srebrny kielich liturgiczny z XVIII wieku z prostą dekoracją czaszy oraz dekoracyjnym nodusem, bez nadmiernej ilości motywów ornamentalnych, które mogłyby stwarzać problemy interpretacyjne $^{31}$. Ostatnim eksponatem, należącym do działu tekstyliów, był XVIII-wieczny, francuski biały ornat liturgiczny. Szata była haftowana, z bordiurą, posiadała wtórną podszewkę, a główna kolumna wykonana była najprawdopodobniej z tkaniny użytej wcześniej do uszycia sukni, o czym świadczą przeszycia w nietypo-

${ }^{31}$ Warto nadmienić, że studenci, mimo iż posiadają pewną wiedzę w zakresie historii sztuki i rzemiosła artystycznego, nie są studentami ani absolwentami historii sztuki. Potrafią rozpoznawać podstawowe motywy ikonograficzne, ornamenty i style w sztuce; są w stanie wstępnie wydatować obiekty. Wiedzą też, z jakich źródeł i opracowań należy korzystać by przygotować profesjonalną dokumentację obiektów. 
wych miejscach. Duża ilość detali, jednak stosunkowo prostych do opisania, była wyzwaniem dla studentów.

Istotnym dla zajęć było również wybranie obiektów, które są charakterystyczne dla zbiorów muzeum religijnego. Pozwoliło to na ukazanie specyfiki pracy w muzeum o tym profilu oraz zasobu wiedzy i umiejętności, które są najbardziej cenione w pracy z obiektami, będącymi trzonem kolekcji. Studenci bardzo szybko uświadomili sobie, że początek prac nad dokumentacją obiektów to również konieczność dalszych, samodzielnych studiów nad ikonografią chrześcijańską, specyfiką i funkcją paramentów liturgicznych oraz technikami ich wykonania.

Zajęcia praktyczne zakładały przygotowanie szczegółowej dokumentacji wszystkich czterech udostępnionych dzieł sztuki. Studenci rozpoczęli od określenia rodzaju obiektów, z którymi muszą pracować. Pierwsze zajęcia w Muzeum Archidiecezji Warszawskiej okazały się bardzo pomocne w rozpoznaniu artefaktów typowych dla liturgii, takich jak szaty czy paramenty. Następnie określane były materiały i techniki. Ten krok oparty był o wiedzę studentów zdobytą podczas zajęć z rzemiosła artystycznego, które w sposób szczegółowy i chronologiczny przybliżały najważniejsze kwestie związane z tzw. sztuką dekoracyjną. Studenci określali też możliwy czas powstania obiektów. Wcześniejsze oprowadzenie kuratorskie i samodzielne zwiedzanie wystawy dały możliwość obejrzenia obiektów pod kątem ich proweniencji i daty powstania, co ułatwiło próbę wydatowania tych, z którymi pracowali, poprzez analizę komparatystyczną.

Kwestią kluczową podczas zajęć w muzeum była możliwość dokładnej analizy dzieł pod kątem stanu ich zachowania oraz użytych technik. Studenci mieli okazję by sprawdzić, jakie zastosowano podobrazie czy z jakiego materiału wykonana jest rzeźba. Umiejętności te, tak ważne dla warsztatu przyszłego muzeologa, wymagają fizycznego kontaktu z przedmiotem, który daje możliwość dokładnego zobaczenia detalu. Przedmioty rzemiosła artystycznego były w tym przypadku szczególnie ważne. Dopiero dokładne oględziny pozwalają na odróżnienie haftu i aplikacji, których trójwymiarowa forma ulega spłaszczeniu na fotografii. Dzięki zajęciom terenowym studenci z bliska analizowali jakość i formę dekoracji ornatu, mieli okazję by zwrócić uwagę na wtórnie wykorzystaną tkaninę czy współczesną podszewkę, o którą uzupełniono ornat. Nauczyli się także, w jakich miejscach pojawiają się sygnatury muzealne, które muszą znaleźć się w dokumentacji oraz zobaczyli gdzie szukać znaków na wyrobach złotniczych.

Opisy stanu zachowania wraz ze wszystkimi ubytkami najlepiej udało się wypracować na przykładzie rzeźby, która miała liczne przetarcia oraz ukruszone fragmenty. Analiza całości dzieła na żywo dała możliwość przestudiowania każdego detalu, obejrzenia materiału w świetle dziennym oraz sporządzenia bardzo dokładnego opisu stanu zachowania. Podobnie sytuacja wyglądała w przypadku ornatu, którego bordiura wymaga uzupełnienia, a w kilku miejscach tkaniny zauważyć można przetarcia i drobne plamy. Wszystkie te elementy, bardzo ważne dla muzeologa, nie są łatwo zauważalne nawet na dobrej jakości reprodukcji.

Istotną kwestią, którą wydaje się warta podniesienia, są również warunki pracy z dziełami sztuki, które zostały przedstawione studentom. Były to pierwsze zajęcia, na których adepci muzeologii zobaczyli jak ważne jest odpowiednie przy- 
gotowanie warsztatu pracy. Odpowiednie oświetlenie ułatwia dokładne oględziny dzieła, duża ilość miejsca na blatach niweluje ryzyko przypadkowego uszkodzenia dzieła, a praca w rękawiczkach jest standardową procedurą ochronną w przypadku kontaktu z artefaktami. Wszystkie wspomniane elementy były niewątpliwie ważną lekcją, która przybliżyła studentów do realiów prac muzealników.

Konkludując, zajęcia w środowisku muzealnym powinny stanowić integralną część zajęć wszystkich przyszłych adeptów muzeologii, z uwagi na wyjątkowy praktyczny walor poznawczy, jaki za sobą niosą. Praca z obiektami, które stanowią część kolekcji pozwala na wykorzystanie nabytej wiedzy teoretycznej w praktyce, co jest niezbędną umiejętnością dla przyszłych pracowników instytucji kultury. Również zasady bezpieczeństwa oraz etyka pracy z materiałem historycznym jest niezwykle istotnym punktem warsztatowego rozwoju studentów. Ponadto praca $\mathrm{w}$ muzeum religijnym zwraca uwagę na marginalizowane często meandry pracy w muzeach wyznaniowych, których poznanie niewątpliwie ubogaca emploi przyszłych muzealników.

\section{BIBLIOGRAFIA}

\section{Źródla}

Ustawa z dnia 23 lipca 2003 r. o ochronie zabytków i opiece nad zabytkami.

\section{Opracowania}

Bochnak A., Zarys dziejów polskiej historii sztuki, Kraków 1948.

Brulon Soares B., A History of Museology Key authors of museological theory, Paryż 2019.

Dolšina M., The Slovenian Art History Textbookin Comparison to Polish Textbooks: Authorship and Content, Didactic Structure and Publishing Circumstances, „Journal of Education Culture and Society", 1 (2014) s. 285-298.

Funkcja pastoralna muzeów kościelnych, thum. ks. Fr. Nieckarz, „Biuletyn Muzeum Diecezjalnego", 4 (2000-2001) s. 5-76.

Jaskanis P., Muzea, muzealia, muzealnicy. Ważne rozmowy, Kraków 2016.

Knell S. J., A Bibliography of Museum Studies, Nowy York 2016.

Leszczyński M., Muzea kościelne wg aktualnego prawodawstwa kościoła katolickiego, „Archiwa, Biblioteki i Muzea Kościelne”, 85 (2006) s. 103-118.

Macdonald S., A Companion to Museum Studies, Oxford 2011.

Muzea w Polsce. Raporty na podstawie danych z projektu Statystyka muzeów (20132015), Narodowy Instytut Muzealnictwa i Ochrony Zbiorów, Warszawa 2016.

Newsom B. Y., Silver A. Z., The Art Museum as Educator: A Collection of Studies as Guides to Practice and Policy, Los Angeles 1978.

Rusak A., Aktualność pastoralnej i dydaktycznej roli polskich muzeów i skarbców kościelnych, w: Muzea kościelne w perspektywie zadań i trendów współczesnego muzealnictwa. Materiały sesji naukowej w dniach 14-15.06.2012, Katowice 2013, s. 31-38.

Program digitalizacji dóbr kultury oraz gromadzenia, przechowywania i udostepniania obiektów cyfrowych w Polsce 2009-2020, Warszawa 2009.

Skrzydlewska B., Muzea kościelne w Polsce. Informator, Kielce 2004.

Skrzydlewska B., Uregulowania prawne kościoła rzymskokatolickiego dotyczace ochrony zabytków, „Archiwa, Biblioteki i Muzea Kościelne”, 77 (2002) s. 287-316. 
Skubiszewski P., Moja historia sztuki, „Modus prace z historii sztuki”, 14 (2014) s. 5-22.

Skubiszewski P., $O$ dwóch sposobach uprawiania historii sztuki, „Teksty”, 17 (1974) z. 5, s. 56-85.

Skubiszewski P., Wstep do historii sztuki, Warszawa 1973.

Woodhead P., Stansfield G., Keyguide to Information Sources in Museum Studies, Londyn 1994.

Wyka E., Taborska M., University Museums in Poland, „Opuscula Musealia Czasopismo Muzeologiczne", 17 (2009) s. 31-40.

Żygulski Jr Z., Muzea na świecie. Wstęp do muzealnictwa, Warszawa 1982.

\section{Netografia}

www.uksw.edu.pl/node/920 (dostęp: 01.07.2018).

nimoz.pl/baza-wiedzy/bazy-danych/baza-studiow-dla-muzealnikow/studia-w-polsce?pdf=1 (dostęp: 29.12.2019).

\section{ANEKS 1. Wykaz przedmiotów na studiach Muzeologia I stopnia}

\begin{tabular}{|c|c|c|}
\hline $\begin{array}{l}\text { Przedmioty humanistyczne i } \\
\text { pokrewne }\end{array}$ & Przedmioty kierunkowe & $\begin{array}{l}\text { Specjalizacja Kolekcjonerstwo } \\
\text { Rzeczoznawstwo Rynek Sztuki }\end{array}$ \\
\hline 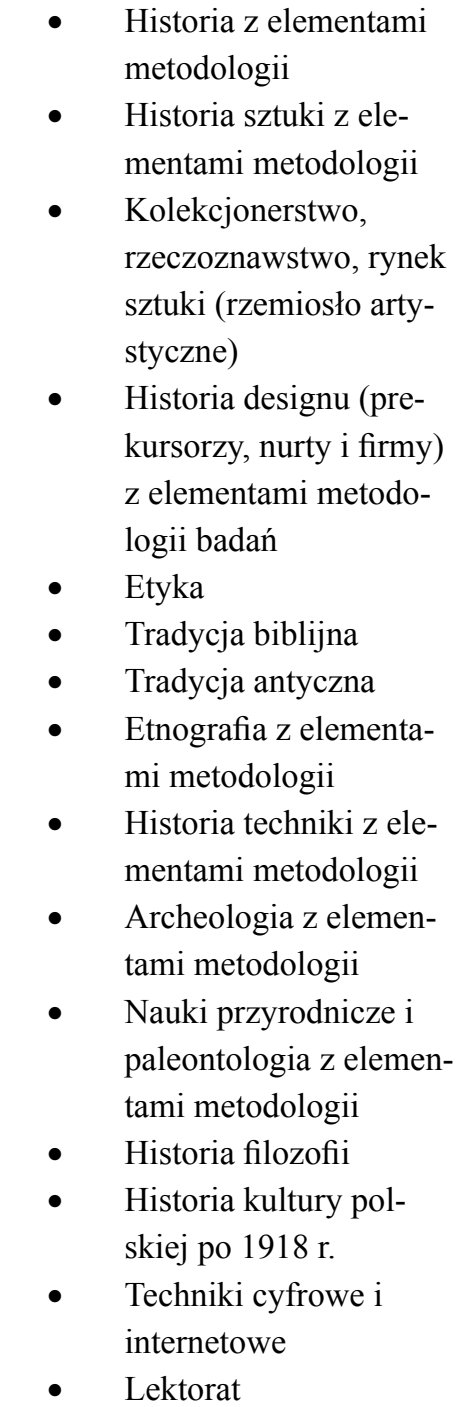 & $\begin{array}{l}\text { - } \quad \text { mstęp do muzeologii i } \\
\text { muzealnictwa } \\
\text { Prawo w muzeum } \\
\text { (ochrona własności } \\
\text { intelektualnej i prawo } \\
\text { autorskie) i zasady } \\
\text { etyki zawodowej } \\
\text { Publikacje muzealne } \\
\text { i praca redakcyjna w } \\
\text { muzeum } \\
\text { Architektura muzeum } \\
\text { - } \\
\text { - } \quad \text { ecjologia w muzeum } \\
\text { dologii } \\
\text { Historia tworzenia } \\
\text { zbiorów i kolekcji (sta- } \\
\text { rożytność - XIX w.) } \\
\text { Gromadzenie zbiorów } \\
\text { muzeum } \\
\text { Działalność naukowa } \\
\text { W muzeum (praca } \\
\text { nad zbiorami sztuki, } \\
\text { archeologicznymi, } \\
\text { etnograficznymi, histo- } \\
\text { rycznymi, biograficz- } \\
\text { nymi, przyrodniczymi i } \\
\text { społecznie wrażliwymi) } \\
\text { - }\end{array}$ & $\begin{array}{l}\text { - } \quad \text { Kolekcjonerstwo } \\
\text { współczesne } \\
\text { Rynek dzieł sztuki - } \\
\text { dzieje i mechanizmy } \\
\text { Rzeczoznawstwo, } \\
\text { metodologia badań i } \\
\text { rozpoznanie stanu za- } \\
\text { chowania dzieł sztuki } \\
\text { Kreowanie marki na } \\
\text { ryku sztuki. Kreowanie } \\
\text { wizerunku artysty, mar- } \\
\text { szanda i antykwariusza. } \\
\text { Kreowanie marki } \\
\text { galerii. } \\
\text { Dokumentacja obiek- } \\
\text { tów } \\
\text { Prawodawstwo polskie, } \\
\text { kościelne i międzynaro- } \\
\text { dowe w zakresie ochro- } \\
\text { ny dóbr kultury } \\
\text { Przestępczość przeciw- } \\
\text { ko zabytkom. Przemyt } \\
\text { sztuki. Falsyfikaty na } \\
\text { rynku antykwarycz- } \\
\text { nym. Straty wojenne }\end{array}$ \\
\hline
\end{tabular}


ANEKS 2. Zakres tematyczny zajęć

Kolekcjonerstwo rzeczoznawstwo rynek sztuki (rzemiosło artystyczne)

[30 h wykład, 60 h ćwiczenia]

- Czym jest rzemiosło artystyczne. Problematyka kolekcjonowania i rynku sztuk dekoracyjnych.

- Najważniejsze kolekcje sztuki dekoracyjnej w Polsce i na świecie. Domy aukcyjne i ich rola w formowaniu się rynku rzemiosł.

- Wstęp do meblarstwa. Niezbędna terminologia. Meblarstwo w starożytności.

- Wieki Średnie - meblarstwo i wyposażenie wnętrz. Główne źródła wiedzy o meblach epoki.

- Renesans - formowanie się nowych odmian mebli, zmiany w wystroju wnętrz. Główne ośrodki produkcji europejskiej.

- Kształtowanie się stylu Ludwików na tle panoramy historyczno-stylowej. Ludwik XIII i Ludwik XIV.

- Styl Ludwika XV i oraz pojawienie się rokoka w Europie.

- Ludwik XVI, klasycyzm, dyrektoriat oraz kształtowanie się stylu empire.

- Styl Ludwika Filipa i Napoleona.

- Panorama wieku XIX. Romantyzm oraz pojawienie się neostylów.

- Poza kontynentem - główne style w meblarstwie i wyposażeniu wnętrz na Wyspach Brytyjskich.

- U zarania współczesności - Secesja i Art Deco.

- Wstęp do porcelany, ceramiki i wyrobów szklanych. Problematyka badań, techniki produkcji oraz niezbędna terminologia. Największe kolekcje ceramiki, porcelany i szkła.

- Najważniejsze huty szkła w Polsce i Europie.

- Historia ceramiki i główne rodzaje naczyń na przestrzeni dziejów.

- Nowożytne ośrodki ceramiczne w Europie i Azji oraz ich charakterystyczne cechy stylowe.

- Pojawienie się porcelany na gruncie azjatycki oraz jej drogi do Europy.

- Wstęp do złotnictwa.

- Złotnictwo świeckie i paramenty liturgiczne.

- Najważniejsze ośrodki złotnicze w Europie i na terenach Polski.

- Tkaniny. Zagadnienia materiałoznawstwa i technik tkackich.

- Typy tkanin i ich cechy stylowe.

- Historia rozwoju tekstyliów.

- Moda i jej historia.

\section{Dokumentacja obiektów}

[30 h ćwiczenia]

- Rodzaje dokumentacji stosowanej w muzeach i domach aukcyjnych.

- Akty prawne dotyczące dokumentacji obiektów.

- Specyfika opisów obiektów architektury.

- Specyfika opisów obiektów ruchomych.

- Praktyczna nauka przygotowania dokumentacji. 


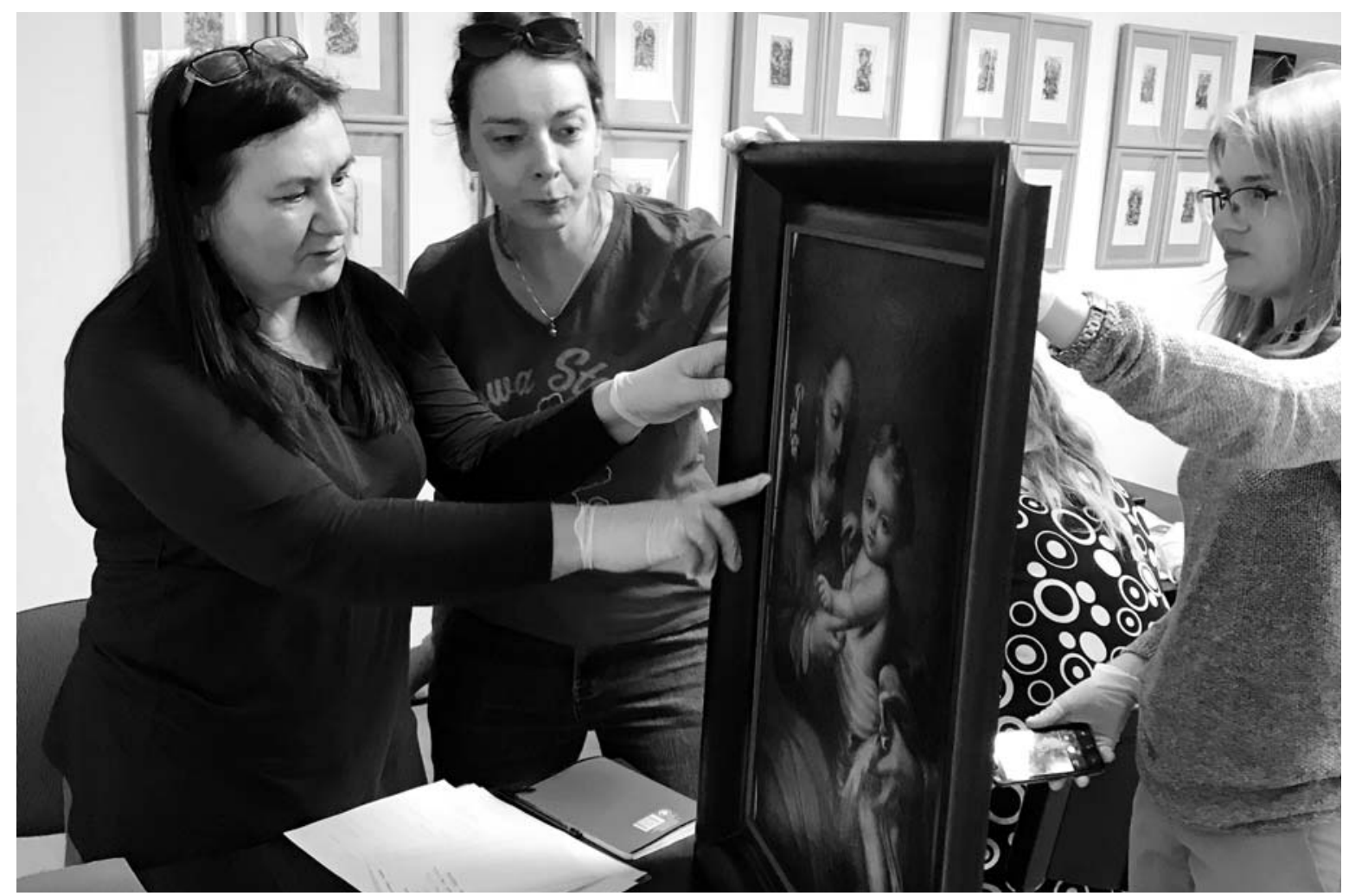

Fot. 1. Studentki muzeologii WNH UKSW przygotowujące dokumentację obrazu. Zbiory autorki.

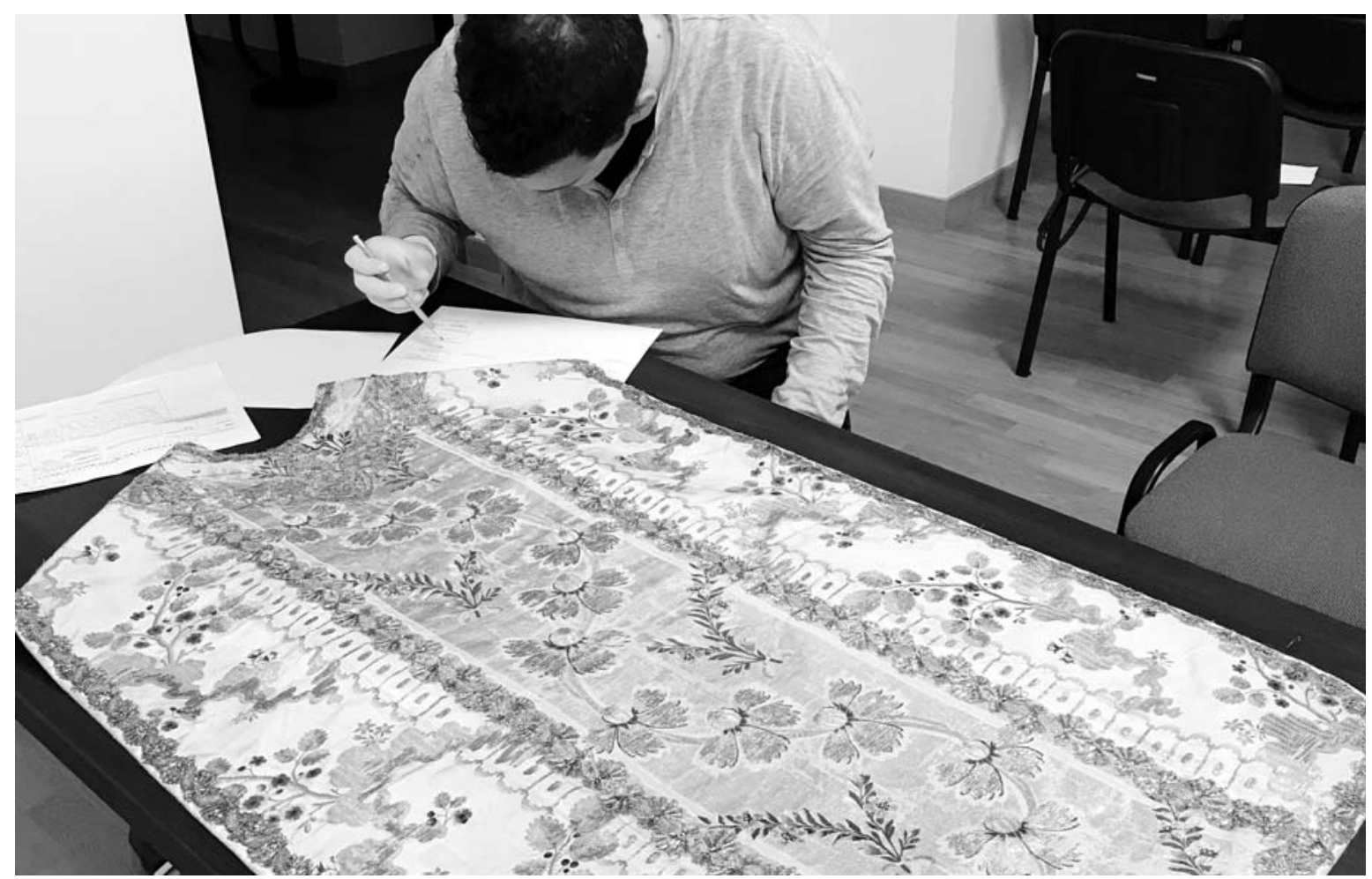

Fot. 2. Student muzeologii WNH UKSW pracujący nad opisem ornatu. Zbiory autorki. 


\section{DECORATIVE ARTS AND DOCUMENTATION CLASSES FOR MUSEOLOGY STUDENTS AT THE WARSAW ARCHDIOCESE MUSEUM}

\section{Summary}

The article presents the Decorative arts and Documentation classes for museology students of the Cardinal Stefan Wyszyński University in Warsaw. The main focal point has been the aspects of the course which were taken at the Warsaw Archdiocese Museum. The theoretical background of decorative arts history, combined with the in-depth course on how to prepare proper artefact documentation, is an integral part of BA Museology studies. Due to the lack of a university museum, it was particularly important to provide students with the opportunity to put theory into practice in a real museum, using techniques and artefacts not available at the university. The text analyses particular questions which were beneficial for museum studies adepts as performed in the professional environment.

Key words: museum studies, decorative arts, artefact documentation, religious art, religious museum, didactics 